\title{
Correction to: Building houses and managing lawns could limit yard soil carbon for centuries
}

\author{
Morgan E. Peach ${ }^{1,2^{*}}$ (D) Laura A. Ogden ${ }^{1,3}$, Eleni A. Mora ${ }^{2}$ and Andrew J. Friedland ${ }^{2}$
}

\section{Correction to: Carbon Balance Manage (2019) 14:9 https://doi.org/10.1186/s13021-019-0124-x}

Following publication of the original article [1], the authors noticed an error in the first paragraph of the Site selection subsection. The text should read, "a cool temperate forested region (mean annual $7.8^{\circ} \mathrm{C}$; $992 \mathrm{~mm}$ precipitation)", instead of "a cool temperate forested region (mean annual $28^{\circ} \mathrm{C} ; 840 \mathrm{~mm}$ precipitation)".

\section{Author details}

${ }^{1}$ Ecology, Evolution, Ecosystems \& Society Program, Dartmouth College, Hanover, NH 03755, USA. ${ }^{2}$ Environmental Studies Program, Dartmouth College, Hanover, NH 03755, USA. ${ }^{3}$ Anthropology Department, Dartmouth College, Hanover, NH 03755, USA
Received: 12 May 2020 Accepted: 12 May 2020

Published online: 23 May 2020

\section{Reference}

1. Peach ME, Ogden LA, Mora EA, Friedland AJ. Building houses and managing lawns could limit yard soil carbon for centuries. Carbon Balance Manag. 2019;14(1):9. https://doi.org/10.1186/s13021-019-0124-X.

\section{Publisher's Note}

Springer Nature remains neutral with regard to jurisdictional claims in published maps and institutional affiliations.

Full list of author information is available at the end of the article

(c) The Author(s) 2020. This article is licensed under a Creative Commons Attribution 4.0 International License, which permits use, sharing, adaptation, distribution and reproduction in any medium or format, as long as you give appropriate credit to the original author(s) and the source, provide a link to the Creative Commons licence, and indicate if changes were made. The images or other third party material in this article are included in the article's Creative Commons licence, unless indicated otherwise in a credit line to the material. If material is not included in the article's Creative Commons licence and your intended use is not permitted by statutory regulation or exceeds the permitted use, you will need to obtain permission directly from the copyright holder. To view a copy of this licence, visit http://creativecommons.org/licenses/by/4.0/. The Creative Commons Public Domain Dedication waiver (http://creativecommons.org/publicdomain/zero/1.0/) applies to the data made available in this article, unless otherwise stated in a credit line to the data. 